\title{
Surfactant Composition and Function in a Primate Model of Infant Chronic Lung Disease: Effects of Inhaled Nitric Oxide
}

\author{
PHILIP L. BALLARD, LINDA W. GONZALES, RODOLFO I. GODINEZ, MARYE H. GODINEZ, RASHMIN C. SAVANI, \\ DONALD C. MCCURNIN, LINDA L. GIBSON, BRADLEY A. YODER, JAY D. KERECMAN, PETER H. GRUBB, AND \\ PHILIP W. SHAUL
}

\begin{abstract}
Department of Pediatrics [P.L.B., L.W.G, R.C.S.], Department of Anesthesiology and Critical Care Medicine [R.I.G, M.H.G.], Children's Hospital of Philadelphia, University of Pennsylvania School of Medicine, Philadelphia, Pennsylvania, 19104; Department of Pediatrics [L.L.G., P.W.S.], University of Texas Southwestern Medical Center, Dallas, Texas, 75390; Department of Pediatrics [D.C.M.], Department of Pathology [B.A.Y.], University of Texas Health Science Center, San Antonio, TX 78229; Southwest Foundation for Biomedical Research [B.A.Y.], San Antonio, Texas 78245; San Antonio Military Pediatric Center [J.D.K., P.H.G.], San Antonio, Texas, 78236
\end{abstract}

\begin{abstract}
Bronchopulmonary dysplasia, or chronic lung disease (CLD), of premature infants involves injury from hyperoxia and mechanical ventilation to an immature lung. We examined surfactant and nitric oxide (NO), which are developmentally deficient in premature infants, in the baboon model of developing CLD. Fetuses were delivered at $125 \mathrm{~d}$ gestation and were managed for $14 \mathrm{~d}$ with ventilation and oxygen prn without (controls) or with inhaled NO at 5 ppm. Compared with term infants, premature control infants had reduced maximal lung volume, decreased tissue content of surfactant proteins SP-A, -B, and -C, abnormal lavage surfactant as assessed by pulsating bubble surfactometer, and a low concentration of SP-B/ phospholipid. NO treatment significantly increased maximal lung volume and tissue SP-A and SP-C, reduced recovery of lavage surfactant by $33 \%$, decreased the total protein:phospholipid ratio of surfactant by $50 \%$, and had no effect on phospholipid composition or SP content except for SP-C (50\%). In both treatment groups, levels of SP-B and SP-C in surfactant were negatively correlated with STmin, with a 5-fold greater SP efficiency for NO versus control animals. By contrast, lung volume and compliance were not correlated with surfactant function. We conclude that surfactant is often dysfunctional in developing CLD secondary to SP-B deficiency. NO treatment improves the apparent ability of hydrophobic SP to promote low surface tension, perhaps secondary to less protein inactivation of surfactant, and improves lung volume by a process unrelated to surfactant function. (Pediatr Res 59: 157-163, 2006)
\end{abstract}

$\mathrm{B}^{\mathrm{P}}$ PD is a common and serious condition among premature infants. The pathogenesis involves interrupted lung development and interstitial fibrosis secondary to oxygen, ventilator treatment, inflammation, and infection imposed upon an immature lung. Infants with severe BPD have continuing oxygen and ventilator requirement that is often complicated by increased pulmonary vascular and airway resistance (1).

Received March 30, 2005; accepted July 26, 2005.

Correspondence: Philip L. Ballard, M.D., Ph.D., ARC416 Children's Hospital of Philadelphia, 3516 Civic Center Blvd., Philadelphia, PA 19104; e-mail: ballardp@email,chop.edu

This work was supported by National Institutes of Health grants HL63399 (P.W.S.), HL56401 (P.L.B.), and HL075900 (R.C.S.). Additional support was provided by HL52636 (BPD Resource Center) and P51RR13986 (facility support). Support by the Gisela and Dennis Alter Endowed Chair in Pediatric Neonatology (P.L.B.) and the Endowed Chair in Critical Care Medicine (R.I.G.) are acknowledged.

DOI: 10.1203/01.pdr.0000190664.69081.f1
Most premature infants are developmentally deficient in pulmonary surfactant, the complex mixture of PL and SP that is required for maintaining alveolar patency (2). In addition, the composition of surfactant at premature birth is abnormal, with a relative deficiency of both saturated phosphatidylcholine, which forms the surface active film, and SP that are essential for formation and stability of film $(3,4)$. Many premature infants who remain on ventilatory support experience episodes of respiratory deteriorations that are associated with dysfunctional surfactant and a reduced concentration of SP-B and SP-C (5).

The signaling molecule NO plays a key role in physiologic processes in the pulmonary epithelium, mediating neurotransmission, smooth muscle relaxation, bacteriostasis, ciliary motility, mucin secretion, and lung liquid production in the perinatal period $(6,7)$. We previously reported that there are maturational increases in NO synthases and NO production, and that NO synthases are deficient in baboon infants with $\operatorname{CLD}(8,9)$. The recognition of NO deficiency in the premature lung, coupled with its effects on vascular and airway resistance, provided the rationale for trials of inhaled NO treatment in infants with severe BPD (10) and more recently in premature infants at risk for BPD $(11,12)$. The efficacy and safety of this therapy remains undetermined, and there is currently little information regarding specific effects of $\mathrm{NO}$ on the immature lung. Both in vivo and in vitro studies suggest that $\mathrm{NO}$ impacts surfactant (13-17), however, this issue has not been examined in premature primates.

To better understand the surfactant status in ventilated infants, and possible effects of replacement NO therapy, we performed studies in the 125-d premature baboon model of

Abbreviations: BAL, bronchoalveolar lavage; BPD, bronchopulmonary dysplasia; CLD, chronic lung disease; PL, phospholipid SP, surfactant protein; STmin, minimum surface tension 
CLD. In this oxygen prn model, infant baboons are ventilated using levels of inspired oxygen as required to maintain normal blood gas values, mimicking the current ventilatory approach for human infants. These animals have a progressive increase in BAL cytokines and demonstrate impaired alveolar development, interstitial fibrosis, and decreased capillary vasculature similar to infant BPD (18). Based on the diverse effects of $\mathrm{NO}$ in the lung and the deficiency of endogenous NO in premature baboons, we treated animals with inhaled NO from birth with the expectation of ameliorating lung disease. We investigated the composition and function of surfactant at $14 \mathrm{~d}$, its relationship to lung function parameters, and the influence of NO therapy. A companion paper describes other responses to NO in the same group of animals (19).

\section{MATERIALS AND METHODS}

Animal model. The animal studies were performed at the Southwest Foundation for Biomedical Research Primate Center in San Antonio, TX with IACUC approval at all participating institutions. Baboon (Papio papio) fetuses were delivered at $125 \pm 2 \mathrm{~d}$ gestation $($ term $=185 \mathrm{~d}$ ) by cesarean section and received surfactant (Survanta, courtesy of Ross Laboratories, Columbus, $\mathrm{OH}$ ) before ventilation with a humidified, pressure-limited, timecycled infant ventilator (InfantStar, Infrasonics, San Diego, CA) or, when necessary, with a 3100A high-frequency oscillatory ventilator (kindly provided by Sensormedics, Yorba Linda, CA). The ventilatory approach was based on a strategy to maintain tidal volume at $4-6 \mathrm{~mL} / \mathrm{kg}$, with adequate chest motion by clinical examination, adjustment of the rate to maintain $\mathrm{PaCO}_{2}$ at $45-55 \mathrm{~mm} \mathrm{Hg}$ and the goal of minimizing exposure to $\mathrm{FiO}_{2}$. Details of this 125-d prn model have been published (18).

Animals were randomly assigned to either controls $(n=11)$ or to NO replacement $(n=8)$ with continuous inhaled NO (5 ppm using an INOVent, iNO Therapeutics, Inc., Clinton, NJ) beginning $1 \mathrm{~h}$ after delivery. A companion paper describes other responses to NO in the same group of animals (19). Ventilatory management was the same for all animals, including a comparable need for high-frequency oscillatory ventilation. BAL was limited to postmortem (d 14) because tracheal aspiration causes significant hemodynamic and pulmonary instability in the premature baboon. BAL was performed similarly on all animals using five saline instillations into the left lower lobe to full distension without ventilatory maneuvers; recovery was $78.0 \pm 3 \%$ control versus $80.2 \pm 2.2 \%$ NO-treated. In addition, lung tissue was obtained at study termination. All NO-treated animals and five controls had their ductus arteriosus ligated on d 6 (regardless of ductus patency). As there were no significant differences in surfactant-related parameters, controls with and without ductal ligation were combined for comparison to the NO-treated group. Tissue and BAL were also obtained from newborn, nonventilated control fetuses at 125, 140,175 d gestation and after term delivery.

Surfactant composition and function. Cells were removed from BAL by centrifugation and the supernatant was centrifuged $(27,000 \times g, 60 \mathrm{~min})$ to yield a large aggregate surfactant pellet and supernatant. Protein (20) and PL $(21,22)$ content were determined and the remaining pellet was diluted to 1.5 $\mathrm{mg} \mathrm{PL} / \mathrm{mL}$ for pulsating bubble surfactometery (3), with minimal surface tension (STmin, $\leq 5 \mathrm{mN} / \mathrm{m}$ defined as normal) of primary interest. Due to the limited amount of available BAL, a single determination of surfactant function was made for each animal; the coefficient of variation for 10 replicate determinations of STmin in a pooled sample was 6\%. PL composition of surfactant was determined by HPLC with refractive index detection using lipid extracted from pooled, residual samples (23). SP-A, SP-B, and SP-C content were analyzed by Western immunoblotting and quantitative immunodot assays as described $(24,25)$.

Tissue studies. Lung homogenate was assayed for SP and content of SP and $\beta$-actin mRNA was determined by dot blot hybridization and Northern analysis (26). Lung tissue was prepared for histopathological analysis (18) and intensity and frequency of SP-B staining (26) was scored by three blinded observers.

Pulmonary function testing. Compliance was determined on d 14 using the VT1000 body plethysmograph (Vitaltrends Technology, New York, NY). Postmortem quasi-static inflation pressure-volume measurements were carried out by inflating the lungs in a stepwise manner $\left(5 \mathrm{~cm} \mathrm{H}_{2} \mathrm{O}\right.$ increments) to a pressure of $20 \mathrm{~cm} \mathrm{H}_{2} \mathrm{O}$. At each increment, the pressure was held for $30 \mathrm{~s}$ and volume was recorded. The lungs were then inflated to $35 \mathrm{~cm} \mathrm{H}_{2} \mathrm{O}$ for 1 min and maximal lung volume was recorded. Pressure was then reduced in steps of $5 \mathrm{~cm} \mathrm{H}_{2} \mathrm{O}$, with stabilization at each step, and recording of volumes.

Statistical analysis. Comparisons between groups were performed by linear regression analysis and by Student's unpaired $t$ test. Significance was accepted at 0.05 . All results are expressed as mean \pm SEM.

\section{RESULTS}

Study groups. As previously described (19), the control and NO replacement groups were comparable for gender distribution, gestational age, and birth weight (Table 1).

Surfactant recovery and composition. BAL was performed at termination of each study. Recovery of total protein was $2.59 \pm 0.37 \mathrm{mg}$ and $1.97 \pm 0.33 \mathrm{mg}$ in control and $\mathrm{NO}$ groups, respectively ( $p=0.25$ ); normalized to body weight, total protein was $6.83 \pm 0.96 \mathrm{mg} / \mathrm{kg}$ and $4.76 \pm 0.79 \mathrm{mg} / \mathrm{kg}$ $(p=0.13)$, respectively. The yield of surfactant PL was $\sim 33 \%$ less $(p<0.05)$ in NO-treated versus both control and term animals calculated per milliliter BAL (Table 2) and $40 \%$ less $(p<0.05)$ normalized to body weight (data not shown). There was a similar decrease (28\%) in content of total PL (surfactant pellet plus supernatant) in BAL of NO animals (data not shown) and no difference between groups in distribution of PL between pellet and supernatant (Table 2).

The total protein content of surfactant pellets from controls was nearly equivalent to the PL content by weight, whereas NO animals had $\sim 50 \%(p<0.05)$ of the control level, comparable to that of term animals (Table 2). This difference in protein:PL ratio reflected both decreased BAL protein and a lower percentage associated with surfactant for the NO group (1.9 versus $3.7 \%$ ).

There were no significant differences in PL composition between groups (Table 2). As expected, phosphatidylcholine was the major species $(\sim 80 \%)$, which is similar to values for other surfactant preparations and the 140-d baboon model $(27,28)$.

Contents of SP-A and SP-B, relative to PL, in surfactant were comparable in NO versus controls, whereas SP-C was significantly decreased by $54 \%$ in NO-treated infants (Table 2). Expressed relative to total protein in the pellet, however, concentrations of all three SP were not different between groups (data not shown). SP-B/PL of both groups was markedly elevated compared with the level in 140-d nonventilated gestational age controls $(<0.05 \% \mathrm{SP}-\mathrm{B} / \mathrm{PL})$, but less than that found in surfactant of nonventilated term baboons (1.90\%). By Western analysis (not shown), only $\sim 8 \mathrm{kD}$ immunoreactive protein was detected in both fractions. By immunodot assay, most of the total BAL SP-B was associated with the surfactant pellet $(86.4 \pm 2.6 \%$ versus $86.2 \pm 3.5 \%$ for controls and NO-treated, respectively). Concentrations of SP-A

Table 1. Characteristics of study animals

\begin{tabular}{lcc}
\hline & Control & iNO \\
\hline Number of infants & 11 & 8 \\
Male/female $(\mathrm{n})$ & $8 / 4$ & $6 / 2$ \\
Gestational age $(\mathrm{d})$ & $125 \pm 2$ & $125 \pm 1$ \\
Birth weight $(\mathrm{g})$ & $382 \pm 15$ & $418 \pm 36$ \\
\hline
\end{tabular}

Data are mean \pm SEM. Eleven control animals were studied, compared with 12 in the other report on this group of animals (20), because BAL was not available for one control animal. 
Table 2. Amount and composition of large aggregate surfactant

\begin{tabular}{lccc}
\hline & $\begin{array}{c}\text { Control } \\
n=11\end{array}$ & $\begin{array}{c}\text { iNO } \\
n=8\end{array}$ & $\begin{array}{c}\text { Term } \\
n=5\end{array}$ \\
\hline PL ( $\mu \mathrm{g} / \mathrm{mL}$ BAL) & $60.0 \pm 4.5$ & $39.8 \pm 2.4^{*}$ & $56.1 \pm 8.3$ \\
PL (\% of total in BAL) & $81.1 \pm 6.9$ & $74.9 \pm 6.6$ & $64.7 \pm 6.7$ \\
Protein (\%PL) & $107 \pm 17$ & $52 \pm 26^{*}$ & $63 \pm 30$ \\
Protein (\% of total in BAL) & $3.7 \pm 0.4$ & $1.9 \pm 0.3^{*}$ & $6.5 \pm 2.0$ \\
SP-A (\% PL) & $6.0 \pm 2.0$ & $4.7 \pm 1.3$ & $9.7 \pm 1.8$ \\
SP-B (\% PL) & $0.75 \pm 0.15$ & $0.49 \pm 0.13$ & $1.9 \pm 0.38^{*}$ \\
SP-C (\% PL) & $10.4 \pm 3.0$ & $4.8 \pm 0.9^{*}$ & $12.5 \pm 9.4$ \\
Phosphatidylcholine (\%) & $84.0 \pm 1.9$ & $75.3 \pm 1.0$ & \\
Lysophosphatidylcholine (\%) & $2.4 \pm 3.2$ & $2.1 \pm 1.2$ & \\
Sphingomyelin (\%) & $8.2 \pm 2.2$ & $14.0 \pm 1.3$ & \\
Phosphatidylinositol (\%) & $3.0 \pm 1.3$ & $6.6 \pm 0.2$ & \\
Phosphatidylglycerol (\%) & $1.7 \pm 0.2$ & $1.4 \pm 0.4$ & \\
Phosphatidylethanolamine $(\%)$ & $0.8 \pm 0.1$ & $0.6 \pm 0.4$ &
\end{tabular}

$* p<0.05$ vs control

NO treatment decreased the protein/PL ratio and percentage of BAL protein in large aggregate surfactant. Recovery of BAL PL in the surfactant pellet was less for NO animals. For comparison, values in term infants are also shown. Phospholipids were determined on pooled, residual surfactant samples and are expressed as percent of total resolved species. Data are mean \pm SE.

and SP-C in both groups were also higher than nonventilated 140-d controls $(<0.1 \%$ and $2.4 \pm 0.7 \%$, respectively) but were not significantly different from term values.

SP in lung tissue. In controls, content of all tissue SP was $<50 \%$ of term with SP-A markedly reduced $(\sim 10 \%)$. Content of SP-B and SP-C mRNA, by contrast, was greater than the term value, whereas SP-A mRNA was low. NO animals had significantly increased content of SP-A, SP-C, and SP-A mRNA (Fig. 1). The levels of SP expression at $14 \mathrm{~d}$ of postnatal life are many-fold higher than those occurring in utero at both $125 \mathrm{~d}$ and $140 \mathrm{~d}$, reflecting postnatal activation of the surfactant system (data not shown).

The gross histopathologic appearance of lung tissue (Fig. 2) was comparable to that previously described (18) and analysis by a panel-of-standards approach found no differences between control and NO-treated lungs (19). SP-B was detected in hyperplastic type II cells, nonciliated airway epithelial cells, and in alveolar macrophages. Using a semiquantitative scoring system for intensity and cellular distribution of SP-B, there were no significant differences between control and NOtreated lungs.
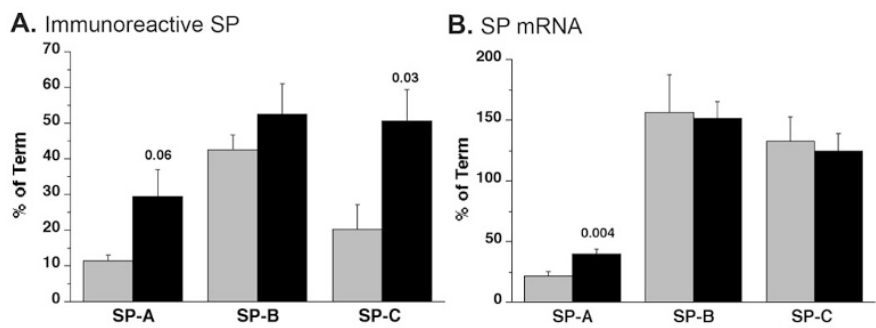

Figure 1. Content of SP $(A)$ and SP mRNA $(B)$ in lung tissue. Immunodot and hybridization (normalized to $\beta$-actin) results for nine control (gray bars) and eight iNO (black bars) animals are expressed as percentage of results for four term animals with $p$ values comparing control and iNO as shown. Content of each SP, in both treatment groups, is less than the term value $(p<$ $0.01)$. Contents of control and NO-treated SP-A mRNA are less than term $(p$ $<0.005)$ and NO-treated SP-B mRNA is greater than the term value $(p=$ $0.03)$.

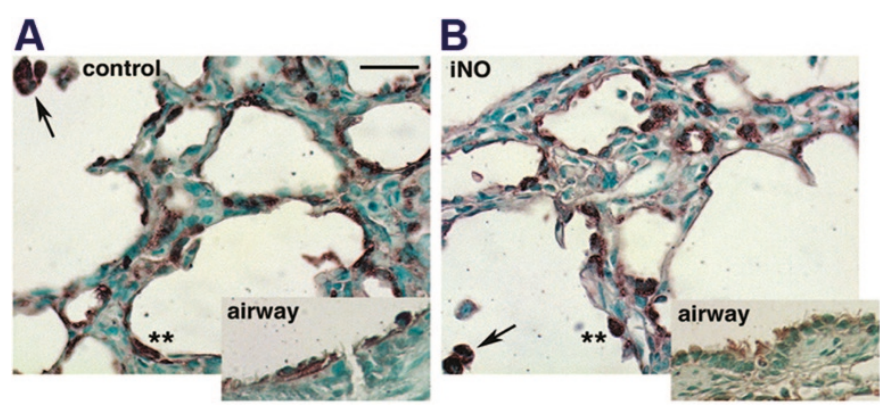

Figure 2. Immunohistochemistry for tissue SP-B. Sections of lung from a control $(A)$ and an iNO-treated $(B)$ animal were immunostained for SP-B and counterstained with methyl green (nuclei). SP-B staining was observed in macrophages (arrows), type II cells (**) and airway epithelial cells (insets); results are representative of six control and nine NO-treated lungs. There were no differences in intensity or distribution of SP-B staining between control and NO animals. Magnification $=300 \times$ for all micrographs $($ scale bar $=25 \mu \mathrm{m})$.

Pulmonary function and surfactant properties. Both dynamic lung compliance, from plethysmography studies on $\mathrm{d}$ 14 , and postmortem maximal lung volume were lower in controls (Table 3) than in term animals (data not shown). Maximal lung volume, but not compliance, was greater in NO-treated versus controls as previously reported (19).

The mean value for STmin, the primary measurement of in vitro surfactant function, was elevated in controls (13.3 $\mathrm{mN} / \mathrm{m}$ ) compared with normal values in term infants and adults $(0-5 \mathrm{mN} / \mathrm{m})(3,29)$. NO exposure did not affect either STmin (mean $10.7 \mathrm{mN} / \mathrm{m}$ ) or the other surface tension parameters (Table 3). STmin values were in the normal range for two control and two NO-treated animals. Unexpectedly, lower STmin was not significantly associated with greater compliance (Fig. $3 A$ ) or maximal lung volume (Fig. $3 B$ ).

SPs and STmin. To examine possible causes for surfactant dysfunction, STmin for individual surfactant samples was compared with SP concentration (Fig. 4). For controls, SP-B and SP-C, but not SP-A or total protein, were negatively correlated with STmin ( $r=0.67$ and 0.60 , respectively), consistent with the role of SP-B/C to promote formation and stability of the surface film (2). Similar negative associations between SP-B/C content and STmin occurred in the NO group, however, the slopes were significantly steeper and the correlation coefficients were higher (0.7-0.8). STmin in NO samples was also negatively correlated with SP-A, in contrast to control samples. These findings suggest that hydrophobic SP in surfactant from NO-treated infants were more efficient in promoting stable film formation.

\section{DISCUSSION}

The premature infant baboon model of CLD was originally developed to reflect oxygen-induced lung disease (classical BPD) of human infants. By contrast, the 125-d gestation baboon ventilated with oxygen prn is a model for the "new" BPD that occurs in many human infants $<30$ wk gestation. The postnatal management, including surfactant treatment and ventilatory strategy, clinical course and histopathology are comparable in the two species. In this study, we evaluated the status of surfactant during the evolution of CLD in the 125-d 
Table 3. Pulmonary function and surfactant properties at termination of studies

\begin{tabular}{lccc}
\hline & Control $(n=11)$ & iNO $(n=8)$ & Term $(n=5)$ \\
\hline Compliance $\left(\mathrm{mL} / \mathrm{cm} \mathrm{H}_{2} \mathrm{O} / \mathrm{kg}\right)$ & $0.53 \pm 0.09$ & $0.68 \pm 0.07$ & \\
Maximal lung volume $(\mathrm{mL} / \mathrm{kg})$ & $32.9 \pm 1.5$ & $46.2 \pm 6.0^{*}$ & $56.7 \pm 6.5^{*}$ \\
Minimum surface tension $(\mathrm{mN} / \mathrm{m})$ & $13.3 \pm 1.7$ & $31.0 \pm 0.6$ & $4.7 \pm 4.1^{*}$ \\
Maximal surface tension $(\mathrm{mN} / \mathrm{m})$ & $32.0 \pm 2.5$ & $166 \pm 60$ & $44.2 \pm 5.2$ \\
Time to minimum surface tension $(\mathrm{s})$ & $108 \pm 25$ & $22.4 \pm 0.2$ & $126 \pm 101$ \\
Adsorption surface tension $(\mathrm{mN} / \mathrm{m})$ & $21.7 \pm 0.3$ & $24.2 \pm 0.7 *$ \\
\hline
\end{tabular}

$* p<0.05$ vs control; +NS vs iNO.

Compliance measurements were made on d 14 just prior to termination of the study, and the other determinations were made post-mortem as described in "Materials and Methods." Compliance data were not available for term baboons.
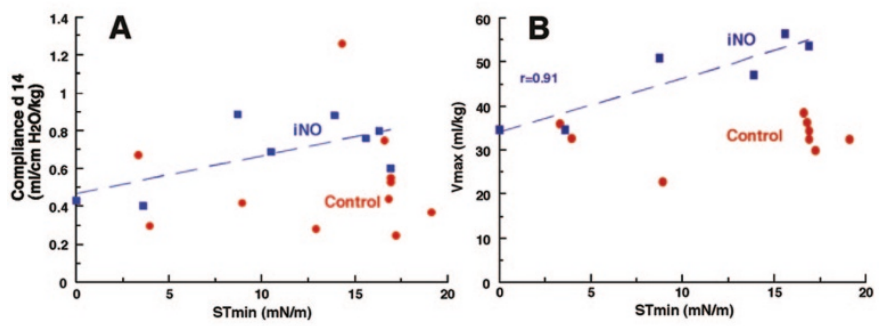

Figure 3. Relationship between lung function parameters and STmin. Compliance data $(A)$ on d 14 before termination are plotted vs STmin of surfactant from postmortem BAL. Maximal lung volume $\left(B, \mathrm{~V}_{\max }\right)$ at $35 \mathrm{~cm} \mathrm{H}_{2} \mathrm{O}$ was measured postmortem. The regression slopes for control plus NO-treated, as well as for each treatment group separately, were not statistically significant $(p>0.08)$; the regression line is shown for NO-treated data in each graph. Data are from 11 control and 8 (compliance) and $6\left(\mathrm{~V}_{\max }\right)$ NO-treated animals.
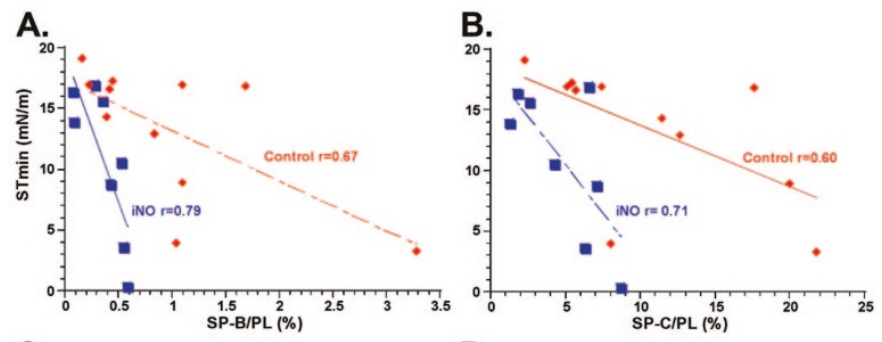

C.
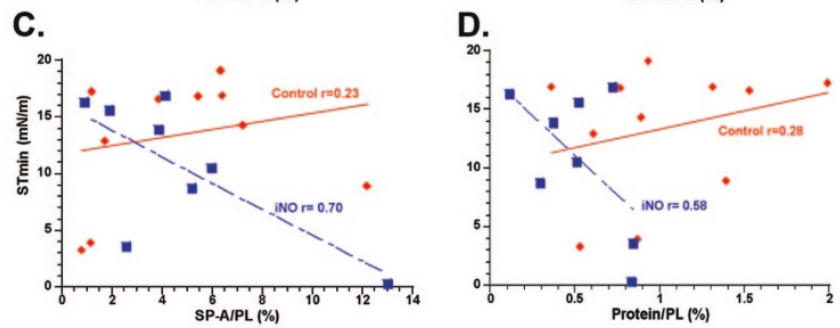

Figure 4. Relationship between SP content and STmin. The concentrations of SP-B $(A)$ and SP-C $(B)$ were negatively correlated with STmin $(r=$ $0.60-0.79, p<0.05$ ) for both groups, however steeper slopes occurred for NO-treated (filled squares, $n=8$ ) vs the controls (filled circles, $n=11, p<$ 0.01 ), indicating a difference in efficacy of the SP to promote low surface tension. SP-A $(C)$ was negatively correlated with $\operatorname{STmin}(r=0.5, p=0.05)$ for NO but not control surfactants. Total protein $(D)$ was not correlated with STmin for either group.

baboon and determined effects of inhaled NO, a treatment currently being studied in clinical trials.

Surfactant in CLD. Previous studies with 140-d, 100\% oxygen infant baboons examined SP gene expression and surfactant surface activity, which was abnormal in 7/10 infants $(4,28,30)$, but these parameters have not been examined in the $125-\mathrm{d}$ model. We found that most of the control (and NO- treated) baboons had dysfunctional surfactant at $14 \mathrm{~d}$, and that SP-B was reduced compared with term animals. The STmin was negatively correlated with concentrations of both SP-B and SP-C, similar to findings in human infants (5) and patients with acute respiratory distress syndrome (31).

Considerable evidence supports a causal relationship between SP-B concentration and surfactant function. SP-B is essential for formation of lamellar bodies, and it promotes rapid film formation as well as stability on compression (2). Absence of SP-B in both mice and humans causes respiratory distress at term delivery due insufficient active surfactant (2). In studies with mice, respiratory failure occurred with $<25 \%$ of normal SP-B concentration, and SP-B $+/$ - animals with $50 \%$ of normal SP-B were more susceptible than wild type to pulmonary infection $(32,33)$. SP-B decreases in animal models of lung injury and infection associated with respiratory distress $(34,35)$. SP-C (at higher concentrations than for SP-B) also promotes surface film formation and stability (36). The content of SP-C in surfactant of control premature baboons was comparable to that of term animals, in contrast to SP-B, indicating that surfactant dysfunction was not likely a result of deficient SP-C. Of note, SP-C concentrations were higher than reported for human infants and adults (3), which could reflect a species difference in either production of SP-C or immunoreactivity.

Several mechanisms for reduced SP-B can be considered. The normal content of SP-B mRNA in 125-d (this study) and 140-d $(4,28,30)$ baboons with CLD does not support transcriptional regulation in this species. The inflammation and oxidative stress associated with hyperoxia and mechanical ventilation may degrade or modify SP; by Western analysis, however, no partially or abnormally processed forms of SP-B were evident. Finally, translational efficiency or processing of SP-B may be altered in CLD, particularly in newly differentiated type II cells (37).

Although SP-A contributes to surfactant film formation and PL recycling, its primary role relates to host defense (38). In previous studies with the 125-d baboon, Awasthi et al. (39) found reduced SP-A mRNA, normal tissue SP-A content, and low lavage SP-A. By contrast, our data indicate reduced levels of both mRNA and protein in tissue but a normal concentration of SP-A in BAL surfactant compared with term animals. These different results may reflect in part the use of antenatal corticosteroid treatment in the Awasthi study but not in the current protocol. 
Effects of NO treatment. Inhaled NO influenced surfactant recovery and composition as well as lung function. The lower recovery of surfactant likely reflects decreased alveolar surfactant content in the NO group, which might be related to reduced synthesis, decreased secretion or increased contaminating lipids. There was no apparent physiologic impact of this $33 \%$ decrease in surfactant as the ventilation index was lower in treated infants over the $14 \mathrm{~d}(19)$.

The protein:PL ratio of surfactant was less in NO animals, reflecting both less BAL protein and less associated with surfactant. Reduced protein content should improve surfactant function due to less protein inhibition and may relate to the observation that NO-treated animals had a steeper slope for SP-B versus STmin. By this analysis, STmin $<5 \mathrm{mN} / \mathrm{m}$ was achieved at $\sim 0.5 \%$ SP-B/PL in NO-treated animals, which is 5 -fold lower than for controls. A similar effect of NO was observed for SP-C. These findings suggest that NO exposure may be associated with less severe lung injury and reduced protein influx. Serum proteins (e.g., fibrinogen, albumin, and $\mathrm{Hb}$ ) inhibit surfactant function in vitro (27), and proteins released from sloughed airway epithelial cells may have similar properties. In addition, anti-inflammatory properties of NO may reduce oxidative and nitrative modifications of SP$\mathrm{B} / \mathrm{C}$ that impair function, resulting in more active SP.

These observations suggest that NO replacement may attenuate inactivation of surfactant by extraneous proteins during CLD. Because volume of surfactant samples was limited, we were not able to examine protein composition or test for inactivation of surfactant by BAL protein. Nevertheless, such a possibility of improved surfactant function is contrary to evidence that treatment with $\mathrm{NO}$ or $\mathrm{NO}$ metabolites can blunt surfactant activity or decrease SP content (15-17) and suggest that inhaled NO, at the concentration used, may protect against oxidant injury and against surfactant inactivation under physiologic conditions.

NO treatment increased the amount of immunoreactive SP-A and SP-C in lung tissue but not in alveolar surfactant. There are several possible explanations for these apparent discrepancies. Alveolar content of SP-A could fail to increase due to either 1) inhibitory effects of NO on intracellular protein processing and/or secretion or 2) stimulatory effects on recycling. SP-C mRNA content was not increased by NO exposure, suggesting that the elevated tissue content of SP-C protein reflects either greater translational efficiency and/or reduced rate of secretion. Alternatively, there could be normal or increased secretion of SP-C in the presence of NO but decreased alveolar content secondary to enhanced clearance. Additional studies in other experimental systems will be required to delineate mechanisms of NO effects on SP synthesis, secretion, and alveolar clearance.

NO treatment was associated with greater lung volume (Table 3) and dynamic lung compliance (19), and decreased expiratory resistance (19). These findings for pulmonary function are consistent with the known role of $\mathrm{NO}$ in the regulation of both bronchomotor tone and peripheral contractile elements in the developing lung (40). We were surprised to find no positive association of in vitro surfactant function with parameters of lung function as observed in adult patients with idiopathic pulmonary fibrosis (29). It is likely, therefore, that the beneficial effects of replacement $\mathrm{NO}$ on pulmonary function in infant CLD reflect primarily nonsurfactant actions. These may include reduced airway resistance secondary to inhibition of smooth muscle cell proliferation and increased tissue compliance resulting from reduced pulmonary edema, interstitial fibrosis or abnormal content or distribution of extracellular matrix components. In a separate manuscript, we describe effects of NO treatment to normalize abnormal elastin deposition and myofibroblast distribution that are characteristic of CLD (19).

Acknowledgments. The authors thank personnel of the BPD Resource Center: the animal husbandry group led by D. Carey and M. Leland, the NICU staff (H. Martin, S. Ali, D. Correll, L. Kalisky, L. Nicley, R. Degan, S. Gamez, and D. Catland), the Wilford Hall Medical Center neonatal fellows, and the UTHSCSA pathology staff (L. Buchanan, K. Symank, Y. Valdes, and K, Mendoza). We also thank Y. Ning and T. McDevitt for technical help.

\section{REFERENCES}

1. Abman SH, Groothius JR 1994 Pathophysiology and treatment of bronchopulmonary dysplasia. Current issues. Pediatr Clin North Am 41:277-315

2. Whitsett JA, Weaver TE 2002 Hydrophobic surfactant proteins in lung function and disease. N Engl J Med 347:2141-2148

3. Ballard PL, Merrill JD, Godinez RI, Godinez MH, Truog WE, Ballard RA 2003 Surfactant protein profile of pulmonary surfactant in premature infants. Am J Respir Crit Care Med 168:1123-1128

4. Minoo P, Segura L, Coalson JJ, King RJ, DeLemos RA 1991 Alterations in surfactant protein gene expression associated with premature birth and exposure to hyperoxia. Am J Physiol 261:L386-L392

5. Merrill JD, Ballard RA, Cnaan A, Hibbs AM, Godinez RI, Godinez M, Truog WE, Ballard PL 2004 Dysfunction of pulmonary surfactant in chronically ventilated premature infants. Pediatr Res 56:918-926

6. Gaston B, Drazen JM, Loscalzo J, Stamler JS 1994 The biology of nitrogen oxides in the airways. Am J Respir Crit Care Med 149:538-551

7. Cummings JJ 1997 Nitric oxide decreases lung liquid production in fetal lambs. J Appl Physiol 83:1538-1544

8. Shaul PW, Afshar S, Gibson LL, Sherman TS, Kerecman JD, Grubb PH, Yoder BA, McCurnin DC 2002 Developmental changes in nitric oxide synthase isoform expression and nitric oxide production in fetal baboon lung. Am J Physiol Lung Cell Mol Physiol 283:L1192-L1199

9. Afshar S, Gibson LL, Yuhanna IS, Sherman TS, Kerecman JD, Grubb PH, Yoder BA, McCurnin DC, Shaul PW 2003 Pulmonary NO synthase expression is attenuated in a fetal baboon model of chronic lung disease. Am J Physiol Lung Cell Mol Physiol 284:L749-L758

10. Banks BA, Seri I, Ischiropoulos H, Merrill J, Rychik J, Ballard RA 1999 Changes in oxygenation with inhaled nitric oxide in severe bronchopulmonary dysplasia. Pediatrics 103:610-618

11. Hascoet JM, Fresson J, Claris O, Hamon I, Lombet J, Liska A, Cantagrel S, Al Hosri J, Thiriez G, Valdes V, Vittu G, Egreteau L, Henrot A, Buchweiller MC, Onody P 2005 The safety and efficacy of nitric oxide therapy in premature infants. J Pediatr 146:318-323

12. Schreiber MD, Gin-Mestan K, Marks JD, Huo D, Lee G, Srisuparp P 2003 Inhaled nitric oxide in premature infants with the respiratory distress syndrome. $\mathrm{N}$ Engl J Med 349:2099-2107

13. Weinberger B, Laskin DL, Heck DE, Laskin JD 2001 The toxicology of inhaled nitric oxide. Toxicol Sci 59:5-16

14. Hallman M, Bry K 1996 Nitric oxide and lung surfactant. Semin Perinatol 20:173185

15. Stuart RB, Ovadia B, Suzara VV, Ross PA, Thelitz S, Fineman JR, Gutierrez JA 2003 Inhaled nitric oxide increases surfactant protein gene expression in the intact lamb. Am J Physiol Lung Cell Mol Physiol 285:L628-L633

16. Haddad IY, Ischiropoulos H, Holm BA, Beckman JS, Baker JR, Matalon S 1993 Mechanisms of peroxynitrite-induced injury to pulmonary surfactants. Am J Physiol 265:L555-L564

17. Robbins CG, Davis JM, Merritt TA, Amirkhanian JD, Sahgal N, Morin FC 3rd, Horowitz S 1995 Combined effects of nitric oxide and hyperoxia on surfactant function and pulmonary inflammation. Am J Physiol 269:L545-L550

18. Coalson JJ, Winter VT, Siler-Khodr T, Yoder BA 1999 Neonatal chronic lung disease in extremely immature baboons. Am J Respir Crit Care Med 160:1333-1346

19. McCurnin DC, Pierce RA, Chang LY, Gibson LL, Osborne-Lawrence S, Yoder BA, Kerecman JD, Albertine KH, Winter VT, Coalson JJ, Crapo JD, Grubb PH, Shaul PW 2005 Inhaled NO improves early pulmonary function and modifies lung growth 
and elastin deposition in a baboon model of neonatal chronic lung disease. Am J Physiol Lung Cell Mol Physiol 288:L450-L459

20. Bradford MM 1976 A rapid and sensitive method for the quantitation of microgram quantities of protein utilizing the principle of protein-dye binding. Anal Biochem 72:248-254

21. Bligh EG, Dyer WJ 1959 A rapid method of total lipid extraction and purification. Can J Biochem Physiol 37:911-917

22. Dittmer JC, Wells MA 1969 Quantitative and qualitative analysis of lipids and lipid components. In: Lowenstein JM (ed) Methods in Enzymology. Academic Press, Inc, New York, pp 482-487

23. Bernhard W, Linck M, Creutzburg H, Postle AD, Arning A, Martin-Carerra I, Sewing KF 1994 High-performance liquid chromatographic analysis of phospholipids from different sources with combined fluorescence and ultraviolet detection. Anal Biochem 220:172-180

24. Ballard PL, Ning Y, Polk D, Ikegami M, Jobe AH 1997 Glucocorticoid regulation of surfactant components in immature lambs. Am J Physiol 273:L1048-L1057

25. Pepe GJ, Ballard PL, Albrecht ED 2003 Fetal lung maturation in estrogen-deprived baboons. J Clin Endocrinol Metab 88:471-477

26. Gonzales LW, Guttentag SH, Wade KC, Postle AD, Ballard PL 2002 Differentiation of human pulmonary type II cells in vitro by glucocorticoid plus cAMP. Am J Physiol Lung Cell Mol Physiol 283:L940-L951

27. Notter RH 2000 Lung Surfactant Basic Science and Clinical Applications. Marcel Dekker, Inc, New York, pp 207-231

28. King RJ, Coalson JJ, deLemos RA, Gerstmann DR, Seidner SR 1995 Surfactant protein-A deficiency in a primate model of bronchopulmonary dysplasia. Am J Respir Crit Care Med 151:1989-1997

29. Gunther A, Schmidt R, Nix F, Abut-Perez M, Guth C, Rosseau S, Siebert C, Grimminger F, Morr H, Velcovsky HG 1999 Surfactant abnormalities in idiopathic pulmonary fibrosis, hypersensitivity pneumonitis and sarcoidosis. Eur Respir J 14:565-573

30. Coalson JJ, King RJ, Yang F, Winter V, Whitsett JA, Delemos RA, Seidner SR 1995 SP-A deficiency in primate model of bronchopulmonary dysplasia with infection. In situ mRNA and immunostains. Am J Respir Crit Care Med 151:854-866
31. Gunther A, Schmidt R, Feustel A, Meier U, Pucker C, Ermert M, Seeger W 1999 Surfactant subtype conversion is related to loss of surfactant apoprotein B and surface activity in large surfactant aggregates. Experimental and clinical studies. Am J Respir Crit Care Med 159:244-251

32. Melton KR, Nesslein LL, Ikegami M, Tichelaar JW, Clark JC, Whitsett JA, Weaver TE 2003 SP-B deficiency causes respiratory failure in adult mice. Am J Physiol Lung Cell Mol Physiol 285:L543-L549

33. Epaud R, Ikegami M, Whitsett JA, Jobe AH, Weaver TE, Akinbi HT 2003 Surfactant protein B inhibits endotoxin-induced lung inflammation. Am J Respir Cell Mol Biol 28:373-378

34. Savani RC, Godinez RI, Godinez MH, Wentz E, Zaman A, Cui Z, Pooler PM, Guttentag SH, Beers MF, Gonzales LW, Ballard PL 2001 Respiratory distress after intratracheal bleomycin: selective deficiency of surfactant proteins B and C. Am J Physiol Lung Cell Mol Physiol 281:L685-L696

35. Ingenito EP, Mora R, Cullivan M, Marzan Y, Haley K, Mark L, Sonna LA 2001 Decreased surfactant protein-B expression and surfactant dysfunction in a murine model of acute lung injury. Am J Respir Cell Mol Biol 25:35-44

36. Ikegami M, Weaver TE, Conkright JJ, Sly PD, Ross GF, Whitsett JA, Glasser SW 2002 Deficiency of SP-B reveals protective role of SP-C during oxygen lung injury. J Appl Physiol 92:519-526

37. Maniscalco WM, Watkins RH, O'Reilly MA, Shea CP 2002 Increased epithelial cell proliferation in very premature baboons with chronic lung disease. Am J Physiol Lung Cell Mol Physiol 283:L991-L1001

38. Crouch E, Wright JR 2001 Surfactant proteins a and d and pulmonary host defense. Ann Rev Physiol 63:521-554

39. Awasthi S, Coalson JJ, Yoder BA, Crouch E, King RJ 2001 Deficiencies in lung surfactant proteins $\mathrm{A}$ and $\mathrm{D}$ are associated with lung infection in very premature neonatal baboons. Am J Respir Crit Care Med 163:389-397

40. Khassawneh MY, Dreshaj IA, Liu S, Chang CH, Haxhiu MA, Martin RJ 2002 Endogenous nitric oxide modulates responses of tissue and airway resistance to vagal stimulation in piglets. J Appl Physiol 93:450-456

\section{Erratum}

In the article, "2-Methyl-3-Hydroxybutyryl-CoA Dehydrogenase (MHBD) Deficiency: An X-linked Inborn Error of Isoleucine Metabolism that May Mimic a Mitochondrial Disease," by Celia Perez-Cerda, et al., appearing in Pediatric Research 58:488-491, 2005, two authors' names were left off. The list of authors should have included Celia Perez-Cerda, the first author, and Antonia Ribes, the last author. The editors regret the error. 